\title{
MYOCARDIUM IS A MAJOR SOURCE OF PROINFLAMMATORY CYTOKINES IN PATIENTS UNDERGOING CARDIOPULMONARY BYPASS
}

Song Wan, MD

Jean-Marie DeSmet, MD $^{\text {a }}$

Luc Barvais, $\mathrm{MD}^{\mathrm{b}}$

Marcelo Goldstein, $\mathrm{MD}^{\mathrm{c}}$

Jean-Louis Vincent, $\mathrm{MD}, \mathrm{PhD}^{\mathrm{c}}$

Jean-Louis LeClerc, MD
Proinflammatory cytokines, such as tumor necrosis factor- $\alpha$, interleukin-6, and interleukin-8, and antiinflammatory cytokines, such as interleukin-10, may play an important role in patient responses to cardiopulmonary bypass. We sought to define whether the myocardium and the lungs serve as important sources of these cytokines under conditions of cardiopulmonary bypass. Ten patients (age $64 \pm 3$ years, mean \pm standard error of the mean) undergoing elective coronary artery bypass grafting were monitored with an arterial catheter, a coronary sinus catheter, and a pulmonary artery catheter. Plasma levels of tumor necrosis factor- $\alpha$, interleukin-6, interleukin-8, and interleukin-10 were measured simultancously in peripheral arterial blood, coronary sinus blood, and mixed venous blood before heparin administration, 1 minute before aortic crossclamping, 5 minutes after aortic declamping, and at $0.5,1$, 1.5 and 2 hours after aortic declamping. The durations of cardiopulmonary bypass and aortic crossclamping were $114 \pm 9$ and $64 \pm 5$ minutes, respectively. Levels of tumor necrosis factor- $\alpha$ and interleukin- 6 were significantly higher in coronary sinus blood than in arterial blood after aortic declamping. Tumor necrosis factor- $\alpha$ and interleukin-6 levels were also higher in mixed venous blood than in arterial blood within 1 hour after declamping. There were no significant differences among the three sampling sites with respect to interleukin-8 and interleukin-10 levels. In one patient who had postoperative myocardial infarction, however, interleukin-8 levels were three times as high as in coronary sinus blood than in arterial blood. These data indicate that the myocardium is a major source of tumor necrosis factor- $\alpha$ and interleukin- 6 in patients undergoing cardiopulmonary bypass. The lungs may consume rather than release proinflammatory cytokines in the early phase of reperfusion. The source under these conditions of the antiinflammatory cytokine interleukin-10 remains to be determined. (J Thorac Cardiovasc Surg 1996;112:806-11)
$\mathrm{H}^{\mathrm{m}}$ eart operations with cardiopulmonary bypass (CPB) are associated with a transient inflammatory response involving release of proinflammatory cytokines, ${ }^{1-10}$ such as tumor necrosis factor- $\alpha$ $(\mathrm{TNF}-\alpha),{ }^{1,7,8}$ interleukin-1 (IL-1), ${ }^{2}$ interleukin-6 (IL-6), ${ }^{3,4,7-9}$ and interleukin-8 (IL-8), ${ }^{5-10}$ and release

From the Departments of Cardiac Surgery, ${ }^{a}$ Anesthesiology, and Intensive Care, ${ }^{c}$ University Hospital Erasme, Free University of Brussels, Brussels, Belgium.

Supported by Fondation pour la Chirurgie Cardiaque, Belgium. Received for publication Dec. 5, 1995; revisions requested Jan. 9, 1996; revisions received March 19, 1996; accepted for publication March 26, 1996.

Address for reprints: Jean-Louis LeClerc, MD, Department of Cardiac Surgery, University Hospital Erasme, Free University of Brussels, Route de Lennik 808, B-1070, Brussels, Belgium.

Copyright (C) 1996 by Mosby-Year Book, Inc.

$0022-5223 / 96 \$ 5.00+0 \quad \mathbf{1 2 / 1 / 7 3 7 8 6}$ of the antiinflammatory cytokine interleukin-10 (IL10). ${ }^{8,10}$ The degree of release of the proinflammatory cytokines is directly related to the duration of ischemia. $^{7,8}$

As yet, the source of these cytokines during and after CPB has not been defined. The myocardium is the first tissue to be considered for this role. The myocardium is capable of synthesizing biologically active TNF- $\alpha$ after endotoxin stimulation. ${ }^{11}$ Endotoxin release ${ }^{1,12}$ and complement component C5a production during $\mathrm{CPB}^{13}$ may play an important role in inducing TNF- $\alpha$. IL- 8 is released during reperfusion of the ischemic myocardium. ${ }^{14}$ In patients with acute myocardial infarction, the myocardium may release IL-6 and IL-8 after recanalization by balloon angioplasty. ${ }^{15}$ Other organs may also contribute to the release of cytokines after ischemia and reperfusion, however; in particular, the lungs 
and the liver are potential sources of IL-6, IL-8, and IL-10. ${ }^{16,17}$ Accordingly, the aim of this study was to determine whether the heart or the lung is the major source organ of TNF- $\alpha$, IL- 6 , IL- 8 , and IL-10 in patients undergoing $\mathrm{CPB}$.

\section{Patients and methods}

Eleven consecutive patients undergoing CPB for elective coronary artery bypass grafting (CABG) were prospectively entered into this study, which was approved by the local ethical committee. All patients provided written, informed consent. Patients were undergoing reintervention, had dysfunction of other organs (kidneys, liver, lungs), or were treated with corticosteroids before operation were not included. One patient in whom the coronary sinus catheter was dislocated during operation was also excluded from the study. The clinical data of the 10 patients studied are shown in Table I.

After induction of anesthesia, a Swan-Ganz thermodilution catheter (model 131H-7F; Baxter Healthcare Corp., Edwards Div., Irvine, Calif.) and a coronary sinus catheter (Pepine 2G, end hole; Webster Labs, Inc., Baldwin Park, Calif.) were inserted by the same anesthetist, with fluoroscopic guidance in each case. Coronary sinus cannulation was confirmed by contrast dye injection and oximetric testing of sampled coronary sinus blood. Although no complications were associated with coronary sinus cannulation, the coronary sinus catheter was withdrawn 2 hours after declamping to minimize any potential risk.

No corticosteroids were administered before or during operation. Similar balanced anesthetic regimens including sufentanil and midazolam were used in all cases. Paralysis was achieved with pancuronium. Cefamandol (Mandol) was given intravenously for 48 hours starting from the induction of anesthesia as antimicrobial prophylaxis. All patients received aprotinin (Trasylol) intravenously at a dose of $280 \mathrm{mg}$ within 30 minutes of the beginning of the operation and also received $280 \mathrm{mg}$ at the beginning of CPB and $70 \mathrm{mg}$ /hour during CPB, infused intravenously by pump. Anticoagulation was achieved with a loading dose of heparin of $3 \mathrm{mg} / \mathrm{kg}$ and further infusions as necessary to maintain an activated clotting time longer than 480 seconds during CPB. After discontinuation of $\mathrm{CPB}$, heparin was neutralized with protamine sulfate at a dose equal to two thirds of the total dose of heparin.

The extracorporeal circuit consisted of a roller pump (Stockert Instrumente Gmbh, Munich, Germany) and a membrane oxygenator (Optima, COBE Cardiovascular, Inc., Arvada, Colo.). Pump flow was maintained at 2.4 $\mathrm{L} \cdot \mathrm{m}^{-2} \cdot \mathrm{min}^{-1}$. A cold crystalloid cardioplegic solution containing a lactated Ringer's solution with potassium chloride, magnesium chloride, and sodium bicarbonate, supplemented by topical slush hypothermia, was used for cardiac preservation. After each distal anastomosis, 80 to $100 \mathrm{ml}$ additional cold cardioplegic solution was delivered through the vein graft. Patients were cooled to around $30^{\circ} \mathrm{C}$. Rewarming began during the final distal anastomosis. The proximal anastomoses were completed with the aid of a tangential clamp after removal of the crossclamp.

Blood samples were drawn simultaneously from an artery (peripheral arterial catheter or the arterial line of
Table I. Clinical data

\begin{tabular}{lc}
\hline No. of patients & 10 \\
Sex (male/female) & $8 / 2$ \\
Age (years) & $64 \pm 3^{*}$ \\
$\quad$ Mean & $53-74$ \\
Range & $1.87 \pm 0.09^{*}$ \\
Body surface area $\left(\mathrm{m}^{2}\right)$ & $114 \pm 9^{*}$ \\
CPB time (min) & $67-169$ \\
$\quad$ Mean & \\
$\quad$ Range & $64 \pm 5^{*}$ \\
Crossclamp time (min) & $36-87$ \\
$\quad$ Mean & $3.4 \pm 0.2^{*}$ \\
$\quad$ Range & \\
No. of grafts
\end{tabular}

*Mean \pm standard error of the mean.

the pump circuit), the coronary sinus, and the distal pulmonary artery portion of the Swan-Ganz catheter at the following time points: (1) before heparin administration; (2) 1 minute before aortic crossclamping; and (3) 5 minutes, (4) 30 minutes, (5) 1 hour, (6) 90 minutes, and (7) 2 hours after aortic declamping. All samples were anticoagulated with ethylenediaminetetraacetic acid, immediately cooled to $4^{\circ} \mathrm{C}$, and centrifuged within $30 \mathrm{~min}-$ utes $\left(3000 \mathrm{~g}\right.$ for 10 minutes at $4^{\circ} \mathrm{C}$ ). Plasma was transferred to a sterile polypropylene test tube and stored at $-20^{\circ} \mathrm{C}$ until assay.

TNF- $\alpha$, IL-6, IL- 8 , and IL-10 levels in the plasma were determined by means of commercially available enzymelinked immunosorbent assays (Medgenix Diagnostics, Fleurus, Belgium). No adjustment was made for hemodilution. The sensitivity was $20 \mathrm{pg} / \mathrm{ml}$ for TNF- $\alpha, 15 \mathrm{pg} / \mathrm{ml}$ for IL-6, $7.8 \mathrm{pg} / \mathrm{ml}$ for IL- 8 , and $14 \mathrm{pg} / \mathrm{ml}$ for IL- 10 .

Data are presented as mean \pm standard error of the mean. Because comparisons were made between paired samples, with each patient serving as his or her own control, and the data were not normally distributed, a Wilcoxon signed-rank test (StatView software Brainpower Inc., Calabasas, Calif.) was used to compare cytokine levels among the three sampling sites at each sampling time point. Statistical significance was attributed to $p$ values lower than 0.05 .

\section{Results}

The clinical data are summarized in Table I. Each patient received at least one internal mammary artery graft on the left anterior descending coronary artery. All patients survived the hospital stay, and no patients required reexploration for bleeding after operation.

Nine of 10 patients were discharged from the intensive care unit on the first postoperative day. The other patient, a 54-year-old man who received three grafts, had the longest duration of CPB (169 minutes) and aortic crossclamping (87 minutes); he required a 10 to $20 \mathrm{mg} \cdot \mathrm{kg}^{-1} \cdot \mathrm{min}^{-1}$ dobutamine infusion for weaning from $\mathrm{CPB}$. In the postoperative period, the patient showed a significant release of 

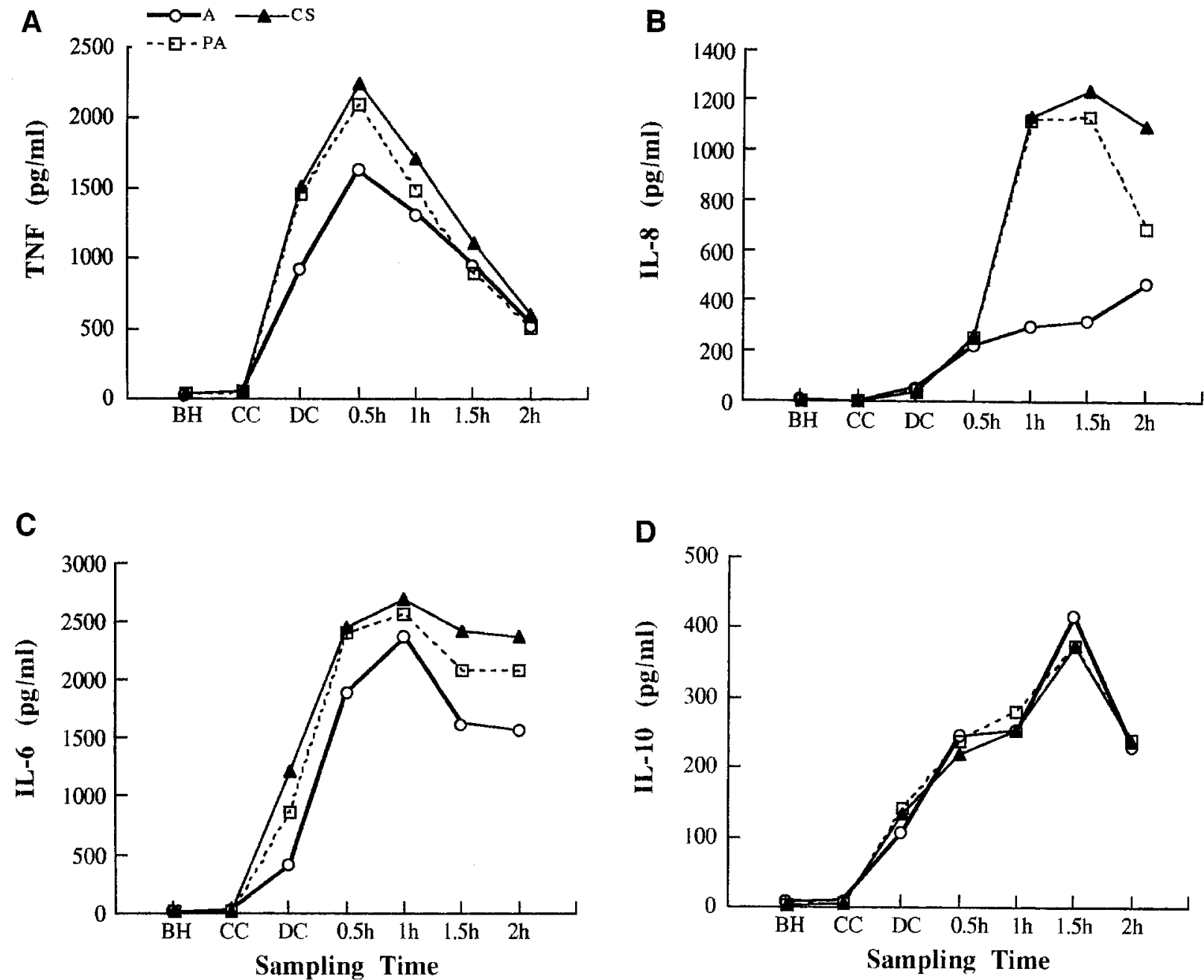

Fig. 1. Plasma levels of TNF- $\alpha$ (A), IL-8 (B), IL-6 (C), and IL-10 (D) in peripheral artery $(A)$, pulmonary artery $(P A)$, and coronary sinus $(C S)$ in one patient undergoing CABG who had postoperative myocardial infarction. $B H$, Before heparin administration; $C C, 1$ minute before aortic crossclamping; $D C, 5$ minutes after aortic declamping; $0.5 h, 1 h, 1.5 h, 2 h$, time points after declamping.

creatine kinase isoenzyme $\mathrm{MB}(69 \mathrm{IU} / \mathrm{L}$ vs $27 \pm 3$ IU/L in the other nine patients), associated with electrocardiographic evidence of myocardial infarction (new-onset $\mathrm{Q}$ waves on leads $\mathrm{V}_{1}$ to $\mathrm{V}_{3}$ ). The levels of the four cytokines measured were 4 to 10 times as high in this patient as in the other nine patients (Figs. 1 and 2). IL-8 levels in this patient, like TNF- $\alpha$ and IL- 6 levels, were much higher in coronary sinus blood than in arterial blood after aortic declamping (Fig. 1).

Cytokine levels in the other nine patients are presented in Fig. 2. TNF- $\alpha$ values increased 5 minutes after aortic declamping and were significantly higher in coronary sinus blood than in arterial blood throughout the study period. IL-6 levels increased slightly later after declamping but were also greater in coronary sinus blood than in arterial blood. Levels of TNF- $\alpha$ and IL- 6 were also significantly higher in mixed venous blood than in arterial blood within 1 hour after declamping. There were no differences in IL- 8 levels among the three sampling sites. IL-10 values were similar among the three sampling sites in all patients (Figs. 1 and 2).

\section{Discussion}

Numerous clinical studies have shown significant elevation of blood cytokine levels during and after 

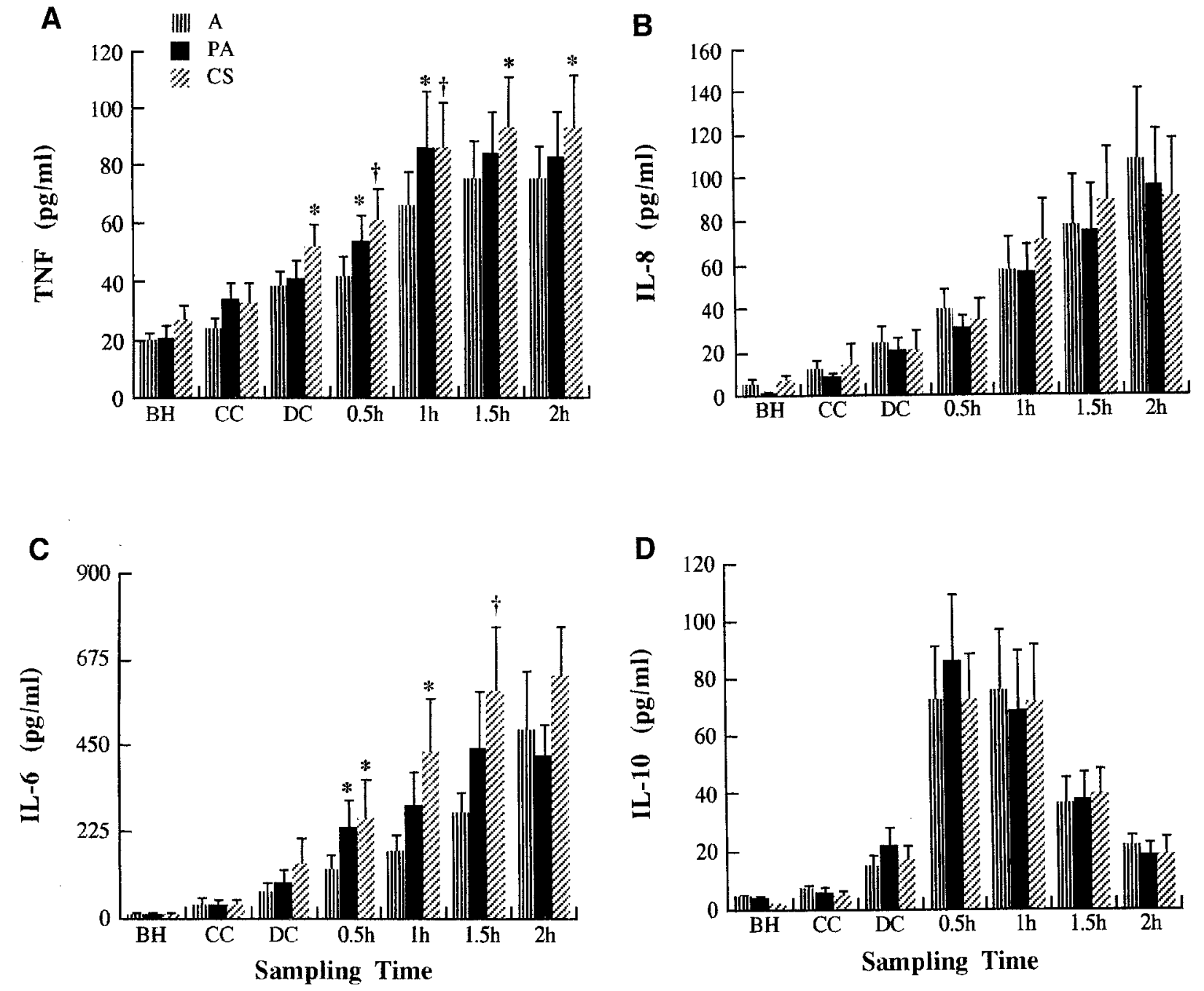

Fig. 2. Plasma levels of TNF- $\alpha$ (A), IL-8 (B), IL-6 (C), and IL-10 (D) in peripheral artery (A), pulmonary artery $(P A)$, and coronary sinus $(C S)$ in nine patients undergoing uncomplicated CABG. Data are mean \pm standard error of mean (error bars). Asterisk indicates $p<0.05$; dagger indicates $p<0.01$ versus arterial. $B H$, Before heparin administration; $C C, 1$ minute before aortic crossclamping; $D C, 5$ minutes after aortic declamping; $0.5 h, 1 h, 1.5 h, 2 h$, time points after declamping.

CPB. ${ }^{1-10}$ Such a phenomenon can be induced by several factors, including ischemia-reperfusion, ${ }^{7,8}$ complement activation, and release of endotoxin. ${ }^{1}$ TNF- $\alpha$ may play an important role in the inflammatory response after CPB, not only because it may directly induce some symptoms, such as fever, tachycardia, and hypotension, ${ }^{18}$ but also because it may trigger the release of other important cytokines, such as IL- $8^{19}$ and IL-10. ${ }^{20}$ IL-6 is a good marker of injury severity, even though it does not have toxic effects itself. ${ }^{21,22}$ IL- 8 is a crucial mediator in ischemia-reperfusion injury in patients undergoing
CPB. ${ }^{5-10} \mathrm{IL}-8$ release is induced only after reperfusion of the ischemic myocardium in animals ${ }^{14,23}$ as well as in human beings. ${ }^{15}$

The release of proinflammatory cytokines may be important because such a release seems to be implicated in the development of postoperative complications. ${ }^{6,7,9}$ A better understanding of these cytokine responses may lead to new therapeutic implications. Administration of anti-IL8 antibodies prevents lung ischemia-reperfusion injury in rabbits. ${ }^{24}$ Anti-TNF antiserum may reduce pulmonary and hepatic injury caused by hepatic ischemia-reper- 
fusion. ${ }^{25}$ Such anticytokine strategies may also be useful in cardiac operations. Removal of TNF- $\alpha$ and IL- 6 by hemofiltration has been shown to have beneficial effects in children undergoing $\mathrm{CPB}^{26}$ Administration of steroids before CPB not only reduces significantly the release of proinflammatory cytokines ${ }^{10,27}$ but also increases the release of IL$10 .{ }^{10}$ In heart and heart-lung transplantation, administration of steroids before the procedure, rather than at the end of CPB as usual, significantly reduces the production of TNF- $\alpha$ and IL- 8 but greatly increases the release of IL-10. ${ }^{28}$

For better insight into the pathophysiology involved, it is important to identify the primary source of these cytokines. There are, however, no reported data indicating the source organ of these cytokines in patients undergoing $\mathrm{CPB}$. To study the myocardial contribution to the release of cytokines, we inserted a catheter into the coronary sinuses of patients undergoing CABG. We found that levels of TNF- $\alpha$ and IL- 6 were significantly higher in coronary sinus blood than in arterial blood, indicating that the myocardium is a major source of these two proinflammatory cytokines in patients undergoing CPB. Furthermore, IL-8 levels in one patient who had postoperative myocardial infarction were three times as high in coronary sinus blood as in arterial blood, suggesting that the myocardium may release IL-8 during more severe injury. Because the data analysis involved multiple comparisons, the degree of statistical significance may have been overstated. Nevertheless, the positive findings were consistent enough to indicate that the observed differences were real.

Our data do not exclude significant cytokine release by other organs. In fact, other organs also have inadequate blood supply during CPB and could similarly be important sources of mediators. Furthermore, the release of endotoxin frequently observed during $\mathrm{CPB}$, as well as complement activation, may trigger the release of cytokines. In particular, the lungs and the liver may play especially important roles because these organs are able to produce cytokines, including TNF- $\alpha$, IL- 6 , and IL-8, in response to different forms of injury. ${ }^{16,17,29}$ The lungs can release TNF- $\alpha$ during ischemia and reperfusion under certain circumstances. ${ }^{29}$ The lungs and liver may contribute to IL- 6 production in thermal injury. ${ }^{17}$ Ischemia-reperfusion of the liver also induces a massive release of IL- $8 .{ }^{16}$ Cytokine release by the lungs, however, would have resulted in higher cytokine levels in arterial blood than in mixed venous blood, and this was not the case in our study. The lungs thus do not contribute significantly to the production of TNF- $\alpha$, IL- 6 , and IL- 8 during and after $\mathrm{CPB}$, at least when the duration of ischemia is relatively short, as it is in routine CABG procedures. In fact, TNF- $\alpha$ and IL- 6 levels were significantly higher in mixed venous blood than in arterial blood shortly after reperfusion, indicating that the lungs may actually consume these proinflammatory cytokines.

Our findings also support some previous observations. For example, Hennein and colleagues ${ }^{7}$ showed that the duration of aortic crossclamping was the only independent predictor of postoperative TNF- $\alpha$ and IL- 6 levels in 22 patients undergoing uncomplicated CABG. $\mathrm{We}^{8}$ recently demonstrated that TNF- $\alpha$, IL-6, and IL-8 levels were much higher in patients undergoing heart transplantation, in whom the duration of myocardial ischemia was much longer, than in those undergoing CABG. Furthermore, the release of IL- 6 and IL- 8 correlated significantly with the duration of ischemia. ${ }^{8}$ Our current data clearly document that TNF- $\alpha$ and IL-6 were released mainly from ischemic myocardium after reperfusion. The myocardium may also be, however, an important source of IL-8 during reperfusion after longer ischemic periods ${ }^{8,30}$ or acute myocardial infarction. ${ }^{15}$ It may be noteworthy that no adjustment was made for hemodilution in our study. If we had done so, the elevation of cytokine levels would have been even greater.

The antiinflammatory cytokine IL-10 is also released during $\mathrm{CPB},{ }^{8},{ }^{10}$ but its tissue source under such conditions still needs to be determined. In this study, IL-10 levels were similar among the three sampling sites, indicating that neither the heart nor the lungs serve as the main source of IL-10 production. The liver may be an important source of IL-10. ${ }^{16}$ Further investigation is required to evaluate this possible mechanism of IL-10 production during CPB.

In summary, this study demonstrates that the heart, not the lungs, is a major source of the proinflammatory cytokines TNF- $\alpha$ and IL-6 after reperfusion of ischemic myocardium in patients undergoing CPB. The lungs may even consume these proinflammatory cytokines under such conditions. Neither the heart nor the lungs are the main source of the antiinflammatory cytokine IL-10.

We thank Professors Alain d'Hollander and Michel Goldman for their help during the study. 


\section{REFERENCES}

1. Jansen NJ, van Oeveren W, Gu YJ, van Vliet MH, Eijsman L, Wildevuur CR. Endotoxin release and tumor necrosis factor formation during cardiopulmonary bypass. Ann Thorac Surg 1992;54:744-8.

2. Haeffner-Cavaillon N, Roussellier N, Ponzio O, Carreno MP, Laude M, Carpentier A, et al. Induction of interleukin-1 production in patients undergoing cardiopulmonary bypass. J Thorac Cardiovasc Surg 1989;98:1100-6.

3. Butler J, Chong GL, Baigrie RJ, Pillai R, Westaby S, Rocker GM. Cytokine responses to cardiopulmonary bypass with membrane and bubble oxygenation. Ann Thorac Surg 1992;53:833-8.

4. Steinberg JB, Kapelanski DP, Olson JD, Weiler JM. Cytokine and complement levels in patients undergoing cardiopulmonary bypass. J Thorac Cardiovasc Surg 1993;106:1008-16.

5. Kalfin RE, Engelman RM, Rousou JA, Flack JE 3rd, Deaton DW, Kreutzer DL, et al. Induction of interleukin-8 expression during cardiopulmonary bypass. Circulation $1993 ; 88(5 \mathrm{Pt} 2)$ : II401-6.

6. Finn A, Naik S, Klein N, Levinsky RJ, Strobel S, Elliott M. Interleukin-8 release and neutrophil degranulation after pediatric cardiopulmonary bypass. J Thorac Cardiovasc Surg 1993;105:234-41.

7. Hennein HA, Ebba H, Rodriguez JL, Merrick SH, Keith FM, Bronstein $\mathrm{MH}$, et al. Relationship of the proinflammatory cytokines to myocardial ischemia and dysfunction after uncomplicated coronary revascularization. J Thorac Cardiovasc Surg 1994;108:626-35.

8. Wan S, Marchant A, DeSmet JM, Antoine M, Zhang H, Vachiery JL, et al. Human cytokine responses to cardiac transplantation and coronary artery bypass grafting. $\mathrm{J}$ Thorac Cardiovasc Surg 1996;111:469-77.

9. Menasché P, Haydar S, Peynet J, Du Buit C, Merval R, Bloch $\mathrm{G}$, et al. A potential mechanism of vasodilation after warm heart surgery: the temperature-dependent release of cytokines. J Thorac Cardiovasc Surg 1994;107:293-9.

10. Tabardel Y, Duchateau J, Schmartz D, Marécaux G, Shahla $\mathbf{M}$, Barvais $\mathbf{L}$, et al. Corticosteroids increase blood interleukin-10 levels during cardiopulmonary bypass in men. Surgery 1996;119:76-80.

11. Kapadia S, Lee J, Torre-Amione G, Birdsall HH, Ma TS, Mann DL. Tumor necrosis factor- $\alpha$ gene and protein expression in adult feline myocardium after endotoxin administration. J Clin Invest 1995;96:1042-52.

12. Andersen LW, Baek L, Degn H, Lehd J, Krasnik M, Rasmussen JP. Presence of circulating endotoxin during cardiac operations. J Thorac Cardiovasc Surg 1987;93:115-9.

13. Chenoweth DE, Cooper SW, Hugli TE, Stewart RW, Blackstone EH, Kirklin JW. Complement activation during cardiopulmonary bypass: evidence for generation of $\mathrm{C} 3 \mathrm{a}$ and $\mathrm{C} 5 \mathrm{a}$ anaphylatoxins. N Engl J Med 1981;304:497-503.

14. Ivey CL, Williams FM, Collins PD, Jose PJ, Williams TJ. Neutrophil chemoattractants generated in two phases during reperfusion of ischemic myocardium in the rabbit: evidence for a role for C5a and interleukin-8. J Clin Invest 1995;95:2720-8.

15. Neumann FJ, Ott I, Gawaz M, Richardt G, Holzapfel H, Jochum M, et al. Cardiac release of cytokines and inflammatory responses in acute myocardial infarction. Circulation 1995;92:748-55.
16. Le Moine O, Marchant A, Durand F, Ickx B, Pradier O, Belghiti J, et al. Systemic release of interleukin-10 during orthotopic liver transplantation. Hepatology 1994;20:88992.

17. Bankey PE, Williams JG, Guice KS, Taylor SN. Interleukin- 6 production after thermal injury: evidence for nonmacrophage sources in the lung and liver. Surgery 1995; 118:431-9.

18. Starnes HF Jr, Warren RS, Jeevanandam M, Gabrilove JL, Larchian W, Oettgen HF, et al. Tumor necrosis factor and the acute metabolic response to tissue injury in man. $\mathrm{J}$ Clin Invest 1988;82:1321-5.

19. Sheron N, Williams R. IL-8 as a circulating cytokine: induction by recombinant tumour necrosis factor-alpha. Clin Exp Immunol 1992;89:100-3.

20. van der Poll T, Jansen J, Levi M, ten Cate H, ten Cate JW, van Deventer SJ. Regulation of interleukin 10 release by tumor necrosis factor in humans and chimpanzees. J Exp Med 1994;180:1985-8.

21. Pinsky MR, Vincent JL, Devière J, Alegre M, Kahn RJ, Dupont E. Serum cytokine levels in human septic shock: relation to multiple-systems organ failure and mortality. Chest 1993;103:565-75.

22. Preiser JC, Schmartz D, Van der Linden P, Content J, Vanden Bussche P, Buurman W, et al. Interleukin-6 administration has no acute hemodynamic or hematologic effect in the dog. Cytokine 1991;3:1-4.

23. Kukielka GL, Smith CW, LaRosa GJ, Manning AM, Mendoza LH, Daly TJ, et al. Interleukin-8 gene induction in the myocardium after ischemia and reperfusion in vivo. $\mathbf{J}$ Clin Invest 1995;95:89-103.

24. Sekido N, Mukaida N, Harada A, Nakanishi I, Watanabe $\mathbf{Y}$, Matsushima K. Prevention of lung reperfusion injury in rabbits by a monoclonal antibody against interleukin- 8 . Nature 1993;365:654-7.

25. Colletti LM, Remick DG, Burtch GD, Kunkel SL, Strieter RM, Campbell DA. Role of tumor necrosis factor $-\alpha$ in the pathophysiologic alterations after hepatic ischemia/reperfusion injury in the rat. J Clin Invest 1990;85:1936-43.

26. Millar AB, Armstrong L, van der Linden J, Moat N, Ekroth $\mathrm{R}$, Westwick $\mathrm{J}$, et al. Cytokine production and hemofiltration in children undergoing cardiopulmonary bypass. Ann Thorac Surg 1993;56:1499-502.

27. Engelman RM, Rousou JA, Flack JE 3rd, Deaton DW, Kalfin R, Das DK. Influence of steroids on complement and cytokine generation after cardiopulmonary bypass. Ann Thorac Surg 1995;60:801-4.

28. Wan S, DeSmet JM, Antoine M, Goldman M, Vincent JL, LeClerc JL. Steroid administration in heart and heart-lung transplantation: is the timing adequate? Ann Thorac Surg 1996;61:674-8

29. Serrick C, Adoumie R, Giaid A, Shennib H. The early release of interleukin-2, tumor necrosis factor- $\alpha$ and interferon- $\gamma$ after ischemia reperfusion injury in the lung allograft. Transplantation 1994;58:1158-62.

30. Oz MC, Liao H, Naka Y, Seldomridge A, Becker DN, Michler $\mathrm{RE}$, et al. Ischemia-induced interleukin-8 release after human heart transplantation: a potential role for endothelial cells. Circulation 1995;92(Suppl 2):II428-32. 